\title{
Application of the Platform Design Toolkit in the Comparative Analysis of the Crowdfunding Shariah Platform Business Model in East Java
}

\author{
Aliya Malikah ${ }^{1}$, M.Ruslianor Maika ${ }^{2}$ \\ \{alyamalikah54@gmail.com¹,mr.maika@umsida.ac.id²
}

Universitas Muhammadiyah Sidoarjo, J1. Mojopahit No.6660 B Sidoarjo Jawa Timur $61271^{1}$, Universitas Muhammadiyah Sidoarjo, Jl. Mojopahit No.6660 B Sidoarjo Jawa Timur $61271^{2}$

\begin{abstract}
New business opportunities implemented in Indonesia have an impact on the banking sector, namely changes in digitalization. Recognized by the business opportunity is shariah crowdfunding, a business that is implemented digitally in the form of a platform. The need for platform identification will be a comparison of the crowdfunding shari'ah business model so that the sharia crowdfunding platform can be used properly without incorrectly choosing the business model. The platform design toolkit that was present created by Simon Cicero was implemented as a comparison of business models specifically in the East Java region. Based on the 9 mapping elements of the platform design toolkit, there are two platforms in East Java that are compared namely the Kandang.in platform and Cooperation.com. The results show that there are similarities and differences in business models for each element of 9 crowdfunding sharia platform mapping with each other implemented in East Java.
\end{abstract}

Keywords: Platform design toolkit, Comparison, Business Model, Shariah Crowdfunding. 


\section{Pendahuluan}

Benedict J. Drasch [1] dalam jurnalnya yang berjudul Integratingthe "Troublemakers": A Taxonomy for Cooperation between Banks and Fintechs, menjelaskan perubahan mendasar karena digitalisasi, yaitu menciptakan permintaan pelanggan yang baru dan memungkinkan berkembangnya layanan perbankan berbasis teknologi yang biasa disebut dengan financial technology (fintech) atau teknologi keuangan. Kedua, peluang bisnis berbasis shariah crowdfunding yang biasanya diterapkan dalam platform pada negara mayoritas muslim Indonesia [2]. Diketahui terdapat banyak platform fintech yang beroperasi di Indonesia.

Sebuah studi yang baru [3] juga meneliti bahwa rata-rata salah satu dari tiga konsumen yang aktif secara digital, menggunakan dua atau bahkan lebih pada layanan fintech. Hal tersebut dapat dapat diperkirakan akan meningkatnya pengguna fintech hingga mencapai rata-rata 52\% secara global. Fintech juga telah menjadi salah satu mekanisme pendanaan yang mendapatkan popularitas sebagai alternative dari kewirausahaan pembiayaan di seluruh dunia[4].

Shariah crowdfunding telah hadir sebagai wujud kemaslahatan dalam sistem crowdfunding dan semakin menjadi perhatian dalam dunia financial technology. Dalam Laporan Stabilitas Industri Jasa Keuangan Islam 2017, crowdfunding telah disorot sebagai pengembangan inti oleh Islamic Financial Services Board (IFSB) yang mengeluarkan prinsip pemandu dan standar dalam sistem keuangan syariah. IFSB tersebut merupakan salah satu otoritas tertinggi dalam keuangan Islam internasional [5]. Penggabungan antara masalah dan peluang-peluang membuat peneliti tergerak untuk melakukan penelitian terkait masalah masalah pada isu di atas, yaitu terdapat 161 platform fintech di Indonesia termasuk perusahan fintech lending dan IKD (Inovasi Keuangan Digital)sehingga perlu adanya perbandingan pemetaan model bisnis yangditerapkan pada tiap platform fintech.

Sebelum melakukan suatu perbandingan, platform fintech tersebut akan diidentifikasi dengan PDT (platform design toolkit). Platform design toolkit adalah seperangkat pemikiran desain dan model sistem kanvas untuk merancang sebuah platform digital dan nondigital. Platform design toolkit (PDT)yangdijabarkan oleh Simon Cicero juga berfungsi sebagai pembantu dalam pembuatan sebuah situs/platform supaya lebih tangguh.

Terdapat sembilan unsur yang dijabarkan oleh platform yang akan diidentifikasi secara jelas, termasuk mitra (selain pemilik platform), peer dan stakeholder eksternal, integrasi dari aspekaspek yang melampaui produksi nilai, seperti mengevaluasi eksternalitas, tata kelola platform, dan inovasi platform yang memungkinkan bekerja lebih mudah dengan kerangka.

Adapun platform yang tertuju pada penelitian ini adalah platform yang berkaitan dengan isuisu di atas, yaitu platform shariah crowdfunding yang telah tercatat sebagai anggota Asosiasi Fintech Syariah Indonesia (AFSI) serta terdaftar maupun mendapat izin dari Otoritas Jasa Keuangan (OJK) atau regulator Sandbox, khususnya pada wilayah Jawa Timur. Platform yang domisilinya dapat dijangkau oleh peneliti, yang bergerak dan telah sesuai dengan isu-isu diatas ialah platform Kandang.in dan Kerjasama.com yang merupakan platform shariah crowdfunding di Jawa Timur.

Jika dilihat dari jenisnya, istilah crowdfunding pada umumnya terdapat empat jenis utama, yaitu berbasis imbalan, berbasis donasi, pinjaman berbasis, dan crowdfunding berbasis ekuitas. Crowdfunding berbasis reward, donation, lending, serta equity[6]. Kedua platform yang akan diteliti dalam penelitian ini akan dibandingkan model bisnis shariah crowdfundingnya dengan platform design toolkit.

\section{Metode Penelitian}

Penelitian ini menggunakan metode penelitian kualitatif.Alasan menggunakan metode tersebut karena penelitian ini melakukan suatu perbandingan dengan cara wawancara tersurat online maupun langsung sebagai validasi platform terhadap model bisnis saat observasi. Nantinya, obesrvasi dan wawancara dilakukan dengan prinsip dari sembilan (9) unsur yang terdapat pada platform design toolkit. 


\section{Pembahasan}

\section{Identifikasi dan Perbandingan Platform Shariah Crowdfunding}

Dari uraian diatas, telah diketahui bahwa terdapat dua platform yang sesuai dengan kriteria penelitian, yaitu platform yang termasuk dalam keanggotaan Asosiasi Fintech Syariah Indonesia (AFSI), karena AFSI adalah salah satu organisasi yang berpegang pada prinsip shariah, dan disahkan oleh OJK sebagai syarat berizinnya suatu platform fintech di Indonesia. Selain itu, platform tersebut harus sudah mendaftar izin usahapada OJK, minimal telah teregulator Sandbox, yakni platform yang telah dalam masa proses perizinan dan pengujian platform.

Platform yang dimaksud dalam penelitian ini ialah platform Kandang.in dan Kerjasama.com.Platform Kandang.in adalah platform yang beroperasi dibidang ternak,yaitu diperuntukan bagi para investor saja. Pengguna atau investor tersebut wajib berusia diatas 17 tahun. Bidang ternak yang dimaksud adalah pengelolaan modalnya dikelola oleh peternak yang telah ditunjuk langsung oleh pihak Kandang.in. Platform Kandang.in memiliki model bisnis equity crowdfunding. Transaksi investasi yang dilakukan dalam platform tersebut merupakan investasi penyertaan modal atau biasa disebut ekuitas, nantinya investor akan memiliki hak atas kepemilikan hewan yang dimodali. Platform yang diidentifikasi berdasarkan sembilan unsur pemetaan, yaitu platform owner, platform stakeholders, peers, partners, transactions, channel and context,services, value proposition, hinggainfrastucture core components.

Berikut pemetaan platform design canvasyang diidentifikasi dari identifikasi platform design toolkit pada platform Kandang.in

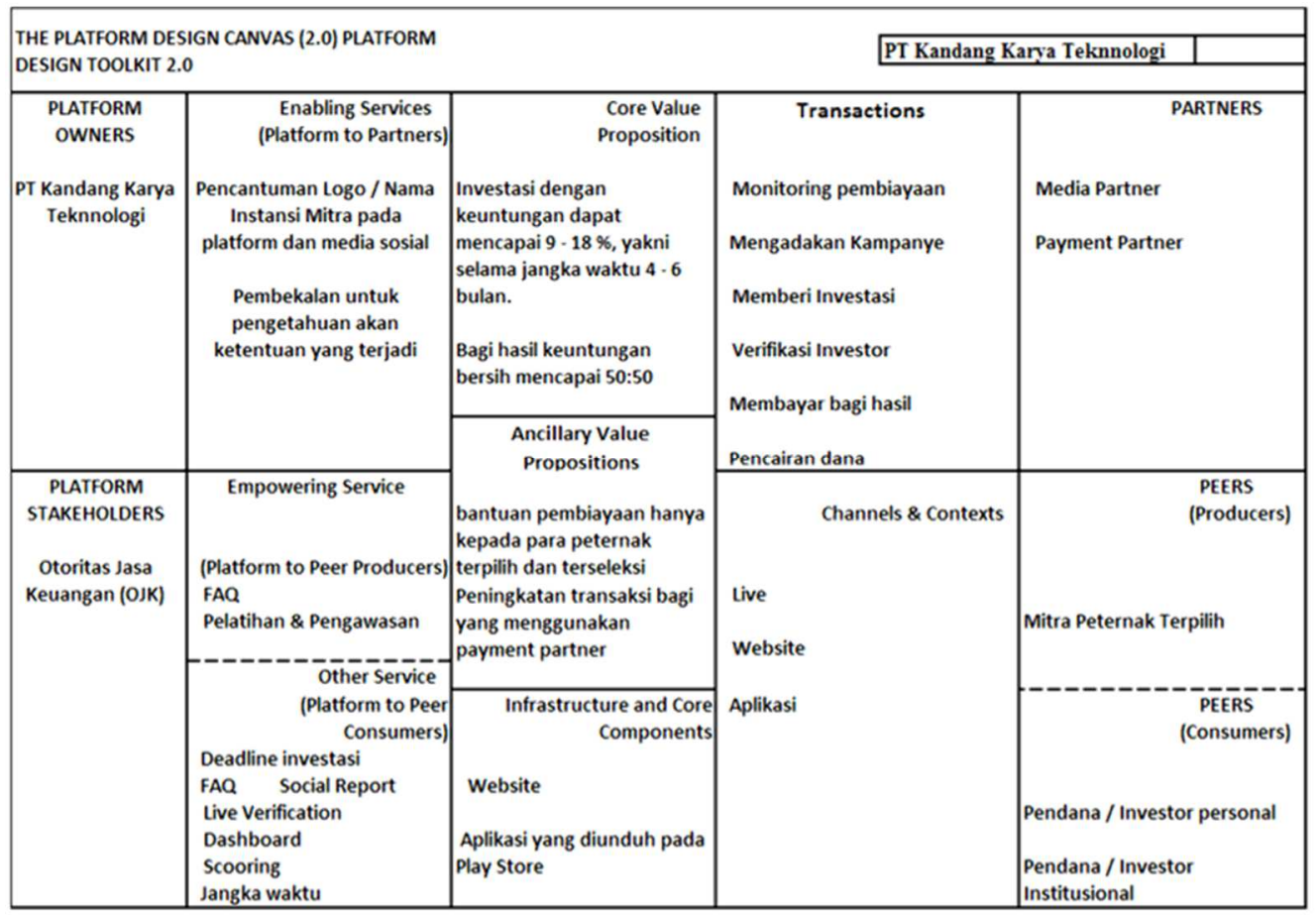

Gambar 1. Pemetaan platform Kandang.in pada platform design canvas yang dipetakan dengan platform design toolkit

Berbeda dengan platform Kandang.in, platform Kerjasama.com menggunakan platform crowdfunding syariah yang berbasiskan properti. Platfrom tersebut memfasilitasi investor serta pemodal dibidang developer dengan para pemangku proyek properti di Indonesia. Lebih tepatnya, platform ini mempertemukan antara investor, developer, dan pemilik lahan untuk melakukan crowdfunding. Platform Kerjasama.com hanya akan menerima pengguna platform sebagai investor apabila telah genap berusia 21 tahun. Salah satu keunggulan yang dimiliki oleh Kerjasama.com 
ialah memiliki verification partner pada platformsehinggapengguna yang menggunakan platform ini terverifikasi dengan baik. Model bisinis Kerjasama.com menggunakan model bisnis berbasis akad syirkah. Berikut pemetaan platform design canvas yang diidentifikasi dari identifikasi platform design toolkit pada platform Kerjasama.com :

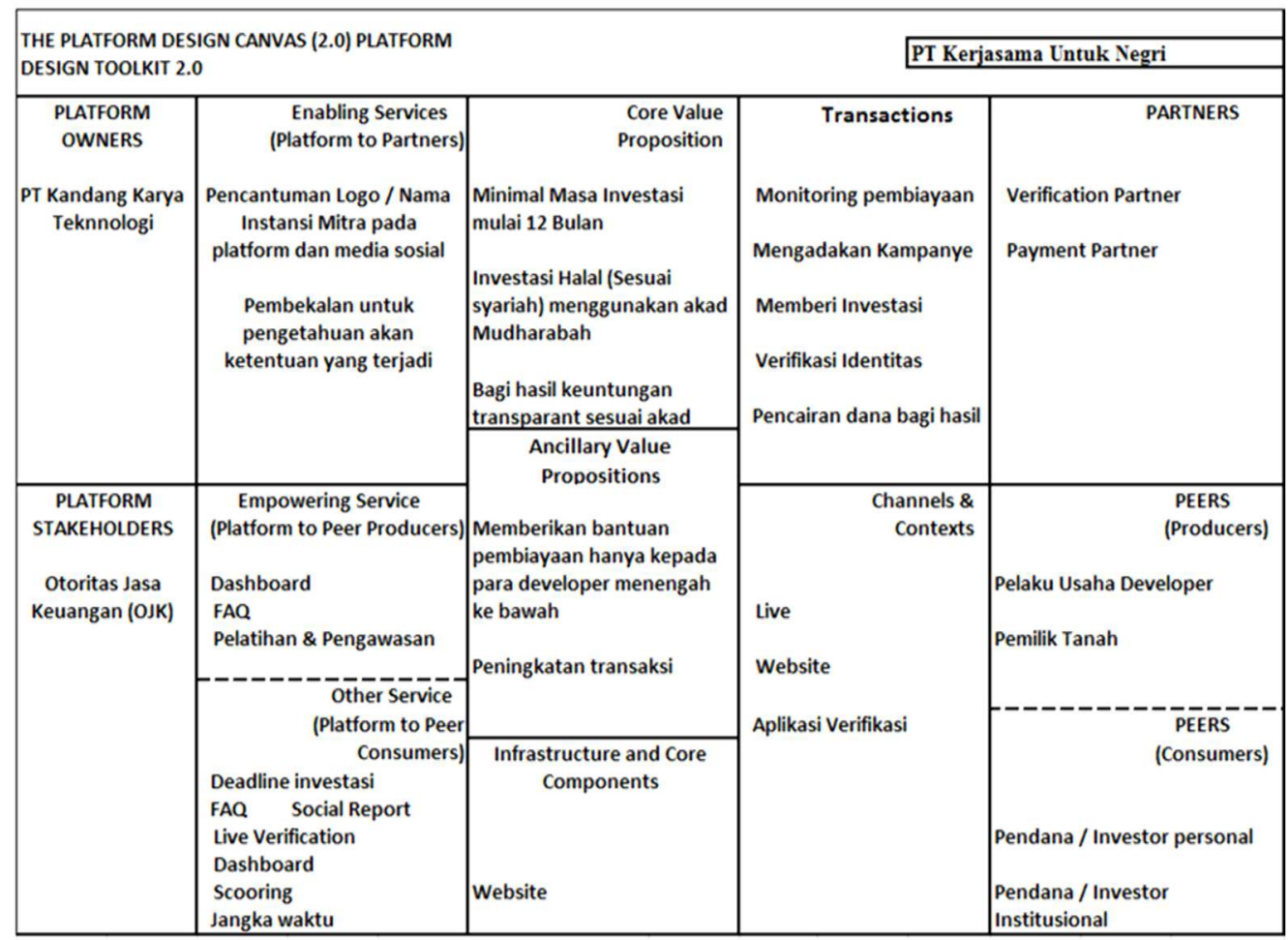

Gambar 2. Pemetaan platform Kerjasama.com pada platform design canvas yang Di petakan dengan platform design toolkit

\section{Kesimpulan}

Kesimpulan dari penelitian ini, terdapatsembilan hasil analisis berdasarkan perspektif platform design toolkit. Penerapan platform design toolkit pada analisis perbandingan shariah crowdfunding sangat membantu untuk memetakan model bisnis, pelaku usaha, hingga pengguna yang menggunakan platform tersebut. Perbandingan dan pemetaan model bisnis lebih cepat dan terstruktur tanpa harus memilah pemetaan apa yang digunakan dalam perbandingan model bisnis karena platform design toolkit sudah memiliki sembilan unsur pemetaan yang dapat digunakan oleh peneliti.

\section{References}

[1] Drasch, Benedict J., André Schweizer, and Nils Urbach, 'Integrating the "Troublemakers": A Taxonomy for Cooperation between Banks and Fintechs', Journal of Economics and Business, 2018, 1-17 <https://doi.org/10.1016/j.jeconbus.2018.04.002>

[2] Wahjono, Sentot Imam, Anna Marina, Widayat, and Muhammad Nasir, 'Islamic Crowdfunding: A Comparative Analytical Study On Halal Financing', Global Conference on Business and Finance, 2 (2017), 1-8

[3] Ernst \& Young, UK FinTech Census 2017, 2017 $<$ https://fintechauscensus.ey.com/2017/Documents/EY-UK-FinTech-Census-2017.pdf>

[4] Wonglimpiyarat, Jarunee, 'Challenges and Dynamics of FinTech Crowd Funding: An Innovation System Approach', Journal of High Technology Management Research, 29 (2018), 98-108<https://doi.org/10.1016/j.hitech.2018.04.009>

[5] Ahammed K, Mushthaq, 'Sharia Compliant Crowd Funding : An Alternative Optimal Platform 
for Funding Msmes', Kaav International Journal of Economics, 4 (2017), 87-93

[6] Vismara, Silvio, 'Sustainability in Equity Crowdfunding', Technological Forecasting and Social Change, 2018, 1-9 <https://doi.org/10.1016/j.techfore.2018.07.014> 